\title{
Process evaluation: The Filles Eveillées ('Girls awakened') program for migrant adolescent girls in domestic service in urban Burkina Faso
}

Leah Jarvis

Gisele Kaboré

Population Council

Follow this and additional works at: https://knowledgecommons.popcouncil.org/departments_sbsr-pgy

Part of the Family, Life Course, and Society Commons, Inequality and Stratification Commons, and the Migration Studies Commons

How does access to this work benefit you? Let us know!

\section{Recommended Citation}

Jarvis, Leah and Gisele Kaboré. 2012. "Process evaluation: The Filles Eveillées ('Girls awakened') program for migrant adolescent girls in domestic service in urban Burkina Faso." Ouagadougou: Population Council. 
PROCESS EVALUATION:

THE FILLES ÉVEILLÉES

(GIRLS AWAKENED) PROGRAM

FOR MIGRANT ADOLESCENT GIRLS

IN DOMESTIC SERVICE IN

URBAN BURKINA FASO

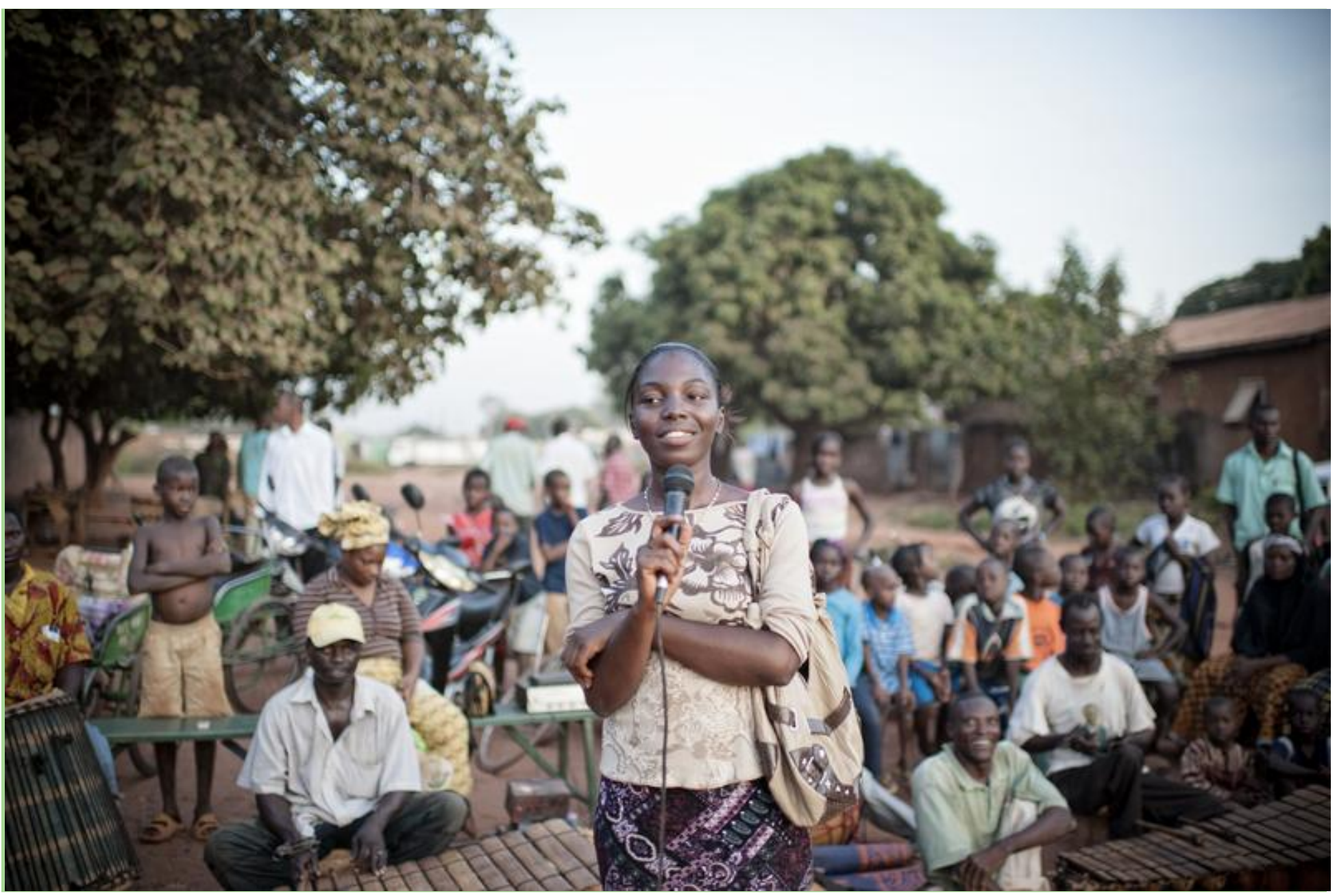




\section{(2) Population Council}

The Population Council confronts critical health and development issues-from stopping the spread of HIV to improving reproductive health and ensuring that young people lead full and productive lives. Through biomedical, social science, and public health research in 50 countries, we work with our partners to deliver solutions that lead to more effective policies, programs, and technologies that improve lives around the world.

Established in 1952 and headquartered in New York, the Council is a nongovernmental, nonprofit organization governed by an international board of trustees.

Population Council

01 BP 6250

Ouagadougou 01

Burkina Faso

www.popcouncil.org

Suggested citation: Leah Jarvis and Gisele Kabore. 2012. “Process Evaluation: The Filles Éveillées (Girls Awakened) Program for Migrant Adolescent Girls in Domestic Service in Urban Burkina Faso." Ouagadougou: Population Council.

Cover photo by Ollivier Girard, courtesy of the Population Council.

(C) 2012. The Population Council, Inc. 


\section{TABLE OF CONTENTS}

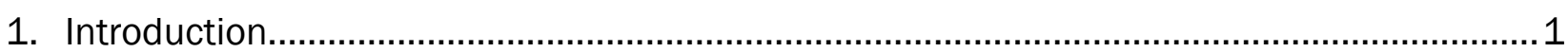

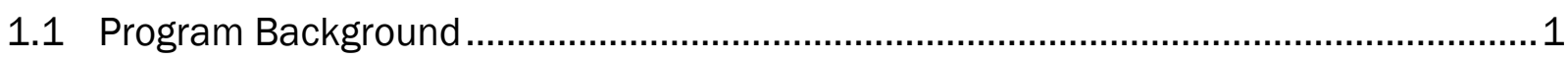

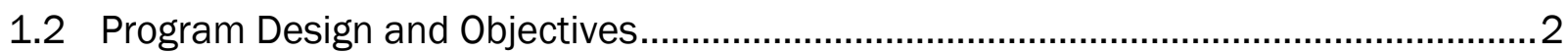

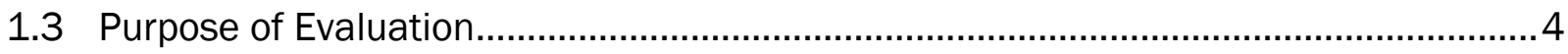

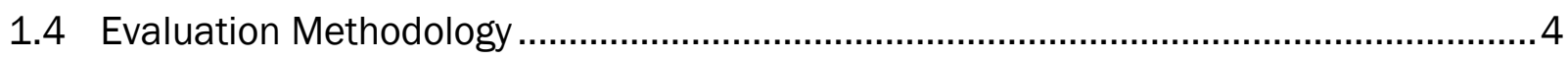

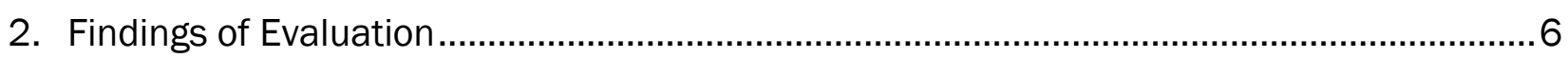

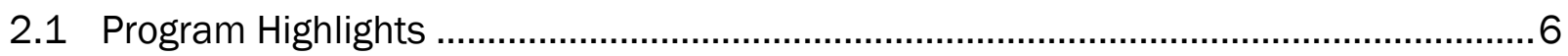

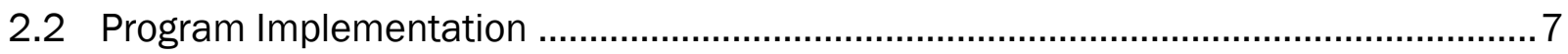

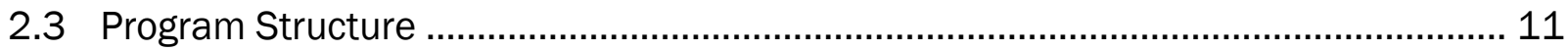

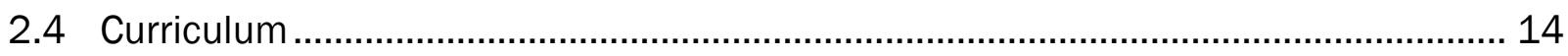

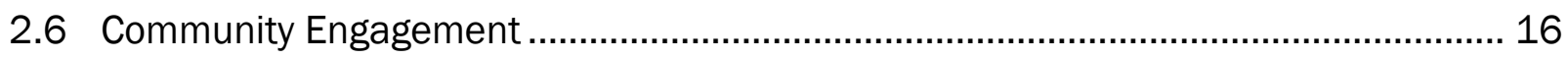

3. Recommendations and Subsequent Changes............................................................ 18



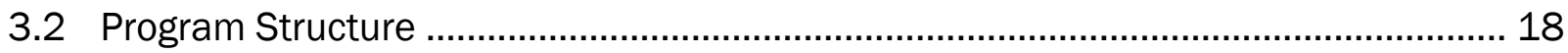

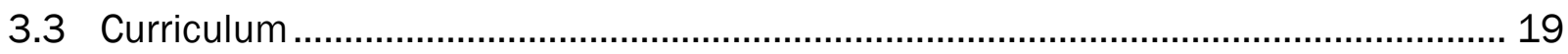

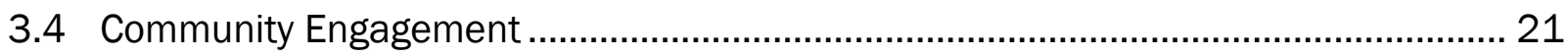

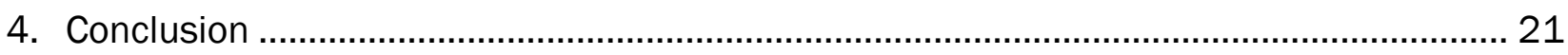

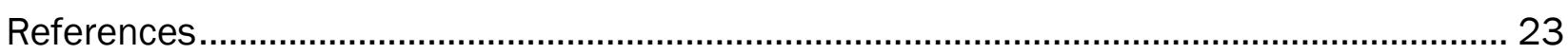

Annex 1: Qualitative Data Collection Tools........................................................................... 24

1.1 Guide de Discussion de Groupe avec les Mentors..................................................... 24

1.2 Guide de Discussion de Groupe pour les Chargés de Programme au Niveau de Tié 26

1.3 Guide d'Entretien pour Membres de la Communauté ................................................ 28

1.4 Guide de Discussion de Groupe pour Filles qui ont Terminé le Programme.............. 29



Annex 2: Monitoring and Evaluation Tools ........................................................................ 33

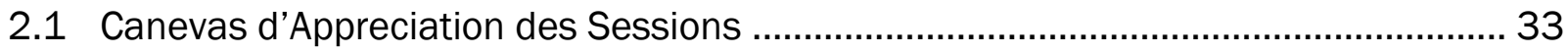

2.2 Tableau de Présence des Filles aux Sessions ........................................................... 35

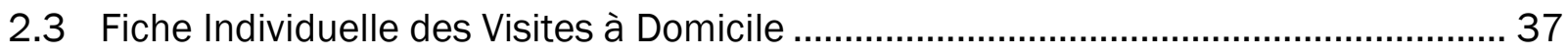

2.4 Fiche de Supervision des Activités des Mentors ........................................................ 38

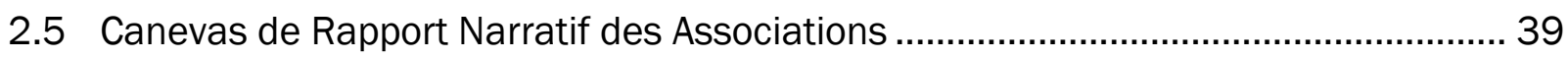

2.6 Canevas du Rapport des Enseignants sur l'Encadrement des Filles du Programme 40 


\section{INTRODUCTION}

The Population Council is a nongovernmental organization that conducts biomedical, social science, and public health research and disseminates evidence to shape more effective policies, programs, and technologies that improve lives around the world. The Council has been working in Burkina Faso since 1989 and has had an office in Burkina Faso since 1994. The Population Council has offices in 15 countries and has worked or currently works in more than 50 countries. The Poverty, Gender, and Youth program conducts research and programs with vulnerable populations such as adolescent girls. Asset-building programs focusing on vulnerable adolescent girls have been successfully piloted in India, Bangladesh, Ethiopia, Kenya, Uganda, and Guatemala, among others, and have been scaled up in almost all of these settings (Population Council, 2012a).

\subsection{Program Background}

Burkina Faso has the tenth youngest population in the world, with 45.2 percent of the population below the age of 15 (Population Reference Bureau, 2011). Burkina Faso is also one of the lowest ranking countries in the world on the Human Development Index, placed at $181^{\text {st }}$ out of 188 countries (United Nations Development Programme, 2011). Given the high rate of poverty and the large numbers of young people, there are few economic opportunities for youth, especially in rural areas. For adolescent girls the situation is still worse, as they typically have little or no education, training, or other forms of work preparation. This drives internal migration to urban areas for both young men and young women in search of work. Young women often find work in domestic service. Some migrate alone, while others are aided by family members or are hosted upon arrival by logeurs ${ }^{1}$. Adolescent migrant girls are vulnerable to physical abuse and economic exploitation and are at increased risk for gender-based violence. Additionally, girls work long days, often live with their employers, and are generally isolated, with no opportunities to make friends, build networks, or go to school. Research has shown that most interventions tend to miss the most vulnerable populations - including adolescent girls, especially those who are out of school and do not live with family (Population Council; Guttmacher Institute, 2010). These populations often do not receive their fair share of services geared toward youth.

In Ouagadougou, over $40 \%$ of girls ages $10-14$ do not live with either parent, and $20 \%$ of girls in this age group do not live with either parent nor are they enrolled in school, making them especially vulnerable and isolated (Population Council, 2009). Formative research conducted by the Population Council found that many of the girls engage in step migration, moving first to a smaller city, such as Bobo Dioulasso, and then after gaining experience in domestic work, migrate on to the capital city, Ouagadougou. Large numbers of domestic workers migrate annually back to their villages of origin during the rainy

\footnotetext{
1 Logeurs are families who have moved from rural villages to urban areas. When migrant girls first arrive in an urban area, they often contact a logeur from their native village and stay with that family until finding employment.
} 
season (generally June to September) in order to help with agricultural work. Age groups and the timeline for the program were based on these findings.

While programs targeting migrant adolescent girls in domestic service already exist in both Bobo Dioulasso and Ouagadougou, most are narrowly focused on mitigating negative outcomes after the fact (such as assistance to victims of sexual violence), professional skills development, or teaching girls about their legal rights. Furthermore, these programs are generally not designed around logical age segments. Population Council found little evidence of programs that aim to build the protective assets of migrant adolescent girls in domestic service. Filles Éveillées actively seeks out this most vulnerable population and aims to reduce vulnerability and increase opportunities by helping to prepare girls for a productive adulthood.

\subsection{Program Design and Objectives}

The program Filles Éveillées ("Girls Awakened") was designed to provide migrant adolescent domestic workers with skills, knowledge, and social capital to reduce their vulnerability and increase their opportunities. Filles Éveillées consists of three key elements for a girl-centered program: a safe space for girls to meet, access to same-sex peers to develop social networks, and a female mentor. A "safe space" is defined as a place where young girls can gather and express themselves freely without the concern of being overheard or observed by others. In many communities, the majority of public spaces or youth centers are dominated by boys and men, making them less than ideal gathering spaces for young girls. Girls often do not have a formal or informal safe place to gather with friends. For the purposes of Filles Éveillées, the safe space must be easily accessible for the girls (no more than a 15-minute walk from the girls' residence or workplace) and be available for the girls' exclusive use during the time of the weekly group meeting. Mentors for Filles Éveillées had to fulfill certain requirements. They were required to be between the ages of 20 and 30 , in order to be old enough to be a role model for the participants but young enough for the girls to feel comfortable confiding in them and relating to them. They had to have completed at least primary school and be literate. Participants in Filles Éveillées had to be migrant adolescent girls working in domestic service, between the ages of 11 and 16 for Bobo Dioulasso and between the ages of 15 and 18 for Ouagadougou.

The three key elements of a girl-centered program assist the girls in developing skills and in improving their social capital, as well as linking them to outside services. Filles Éveillées was developed by the Population Council, funded by the Jacobs Foundation, and is being implemented by local partners in Burkina Faso with technical support from both the Population Council Burkina Faso and the Population Council Headquarters in New York. The implementing partner in Bobo Dioulasso is Association Tié. The implementing partner in Ouagadougou was the Association Songui Manégré Aide au Développement Endogène (ASMADE) in 2011 and the Association d'Appui et d'Éveil Pugsada (ADEP) in 2012-2013. 
The project consists of a three-year grant to implement a skills-building curriculum which will reach a total of 300-400 adolescent girls in domestic service in Ouagadougou and Bobo Dioulasso. There are two program cycles in each location, one from November 2011 to July 2012 and a second from November 2012 to June 2013. The program was designed to consist of weekly group sessions with a mentor, each 60-90 minutes long, over the course of eight months. The timing of the program, from November to June, coincides with the time period in which these girls live and work in cities. There are a total of 30 sessions for each cycle. The sessions are organized into four modules: life skills, financial literacy, health and hygiene, and reproductive health.

\section{Curriculum development}

The curriculum for the 30 sessions was developed by Population Council staff in Burkina Faso and in the headquarters in New York City. It was based on formative research and on existing curricula used in other, similar programs, such as the Biruh Tesfa Program for Adolescent Girls in Ethiopia and the Adolescent Safe Spaces, Health, and Skills for Adulthood in Urban Ghana program. The four modules and 30 sessions were chosen based on needs revealed by the formative research and on time constraints of the target population. The curriculum was written in French and key words were translated into Dioula and Mooré, the two primary languages spoken in Bobo Dioulasso and Ouagadougou, respectively. Each session began with clear objectives for what program participants should be able to do by the end of the session and was designed to be interactive to encourage participation and engagement. The curriculum was submitted to partner organizations prior to their training, to gather feedback which was then incorporated. Each organization was responsible for choosing one session from each module and pilot testing it with eligible girls in their community. Feedback was collected and incorporated once more. A new draft was submitted and was used during the mentor training, during which time a final round of feedback from the mentors and the associations was collected and incorporated. The curriculum was finalized in October 2011, prior to the beginning of the weekly sessions.

\section{Community engagement}

Filles Éveillées has three elements developed specifically to garner community engagement. The first is meetings with community leaders. Implementing partners sought to meet community leaders in their respective districts in order to inform them about the program, request the use of community spaces, and gain their support for the program. The second is community awareness sessions, three of which are held over the course of the program cycle in each participating neighborhood. These sessions are meant to disseminate information about the program, answer questions from the community, and garner community support. The third is home visits, conducted by mentors at the participants' respective residences. Mentors are expected to make at least three visits to each girl's employer over the course of the eight months of the program, and additional visits in the event of any problems with the employer or expressed by the girl, or in the event of repeated absences. The purpose of these home visits was to strengthen the relationship between the mentor and the employer, strengthen the relationship between 
the employer and employee and resolve any problems existing between the two, and keep the employer informed of the program and the employee's progress.

\section{Optional literacy arm}

While the Population Council recognizes the importance of literacy training, its timeconsuming nature coupled with the limited free time available to the target population meant that it could not feasibly be made a central element of Filles Éveillées. Instead, Filles Éveillées initially intended to offer participants the opportunity to enroll in literacy courses in additional to weekly sessions. These courses would teach the girls to read, write, and do basic calculations in the local language - in the case of Bobo Dioulasso, in Dioula, and in Ouagadougou, in Mooré. However, the girls overwhelmingly expressed that they were more interested in learning to read and write in French, and that this would serve them better in the long run. As a result, the girls were instead offered the option of enrolling in evening classes. The cours du soir ("evening classes") allow adolescents or adults who have never been to school or who have not finished school the opportunity to gain primary or secondary education, starting at any level.

\section{Program training}

In preparation for the program, the Population Council held a training for implementing partners. These organizations were in turn expected to hold a training for mentors. Mentors then recruited participants in their respective neighborhoods.

The first cycle took place from November 2011 to June 2012, and the second will take place from November 2012 to June 2013. The first cycle aimed to reach a minimum of 60-70 girls in Bobo Dioulasso and 100 girls in Ouagadougou. The mentors in Bobo Dioulasso recruited 90 girls (30 in each of three groups) and 150 girls in Ouagadougou (30 in each of five groups) in order to compensate for attrition and mobility.

\subsection{Purpose of Evaluation}

The Process Evaluation seeks to evaluate several aspects of the Filles Éveillées program in order to make improvements for the second cycle, beginning in November 2012. Specifically, the Process Evaluation seeks to assess:

- Elements of the program that were or were not implemented as planned and obstacles to implementation; and

- Improvements that can be made to the structure, implementation, and program content in order to more effectively reduce vulnerability of the target population and increase their opportunities.

\subsection{Evaluation Methodology}

The methodology for this evaluation was the collection of primary qualitative data from July 9-12, 2012 and careful analysis of primary quantitative and qualitative data collected over the course of the program using monitoring and evaluation tools. Focus group guides and in-depth interview guides were written by an intern and the Program 
Coordinator for the Population Council Burkina Faso. Focus groups and in-depth interviews were conducted in Dioula and transcribed into French by an independent consultant. Focus group and in-depth interview guides (in French) are available for reference in Annex 1. A variety of monitoring and evaluation tools were created by the Population Council prior to the launch of the program and were filled out by mentors and partner organizations throughout the program (see Annex 2). These tools were examined for the uses of this evaluation.

These monitoring and evaluation tools included:

i. Reports on activities and sessions written by mentors:

a. Mentors' activity reports for each session (Canevas d'Appréciation des Sessions)

b. Attendance data for each session (Tableau de Présence des filles aux Sessions)

c. Individual forms for home visits (Fiche Individuelle des Visites à Domicile)

ii. Mentor supervision sheets written by the Association Tié (Fiche de Supervision des Activités des Mentors)

iii. Three quarterly reports submitted to the Population Council by the Association Tié according to report guidelines (Canevas de Rapport Narratif des Associations)

iv. Student progress summary written by teachers from the cours du soir (Canevas du rapport des Enseignants sur l'Encadrement des Filles $d u$ Programme)

v. Feedback on curriculum gathered by the Association Tié, the implementing partner in Bobo Dioulasso

Primary qualitative data collected included:

i. Two focus groups with program participants (one group of 15 girls, Sector 9/10, and one group of nine girls, Sector 2);

ii. Two focus groups with community members (one group of seven women, one group of five men);

iii. One focus group with the three members of the Association Tié responsible for Filles Éveillées;

iv. Two focus groups with program mentors (three in each group);

v. Three in-depth interviews with employers; and

vi. An informal interview with the Population Council's Program Coordinator. 


\section{FINDINGS OF EVALUATION}

The findings of this evaluation will be organized into five main areas: program highlights, program implementation, program structure, program content, and curriculum.

\subsection{Program Highlights}

Overall, focus group discussions and in-depth interviews revealed that Filles Éveillées was well received and appreciated by employers, community members, and participants. Everyone interviewed lauded the Association Tié, Population Council, and the mentors for their work and for the development of the program. All employers who were interviewed stated that they would certainly recommend the program to others and would let other domestic workers participate in the future. Employers and both male and female community members highlighted that after participating in Filles Éveillées, participants were more respectful, more stable (less likely to switch employers frequently), had better personal hygiene, and do a better job cleaning. Female community members commented that employers are less likely to mistreat girls or pay them irregularly. Employers said they appreciated that the girls had learned to save money and to read and write, and also that the program addressed themes such as sexuality that they themselves would not talk about with their employees. Several employers and community members also noted the benefits of the participants' willingness to share their knowledge with others, both with the children in the employers' household and with others in their home villages. Mentors lauded the opportunity given to girls to make friends, an option they often do not otherwise have. Finally, participants themselves listed some of their favorite benefits as learning to save money, learning to protect themselves from pregnancy and HIV, and going to school.

'Before the program we didn't know anything about AIDS, cancer, gonorrhea. What really pleased me about the program was learning about diseases." -12-year-old program participant

"One day [my employee] told me that before, women had a lower position but today a woman has the same rights as a man; if she studies hard, she can become like a man. That really struck me and stayed stuck in my head." -Female employer

"The program has really been beneficial for the girls. They have changed physically, in their way of speaking and of listening."

-Female community member

"Us mothers, we're embarrassed to talke about sexuality with our girls. When they go to the sessions, they learn a lot of things there. I'm really happy. We never give information concerning menstruation." -Female employer

The element that was most commonly cited as differentiating this program from others was the manner of involving the community. Community members, mentors, and employers all commended the efforts of the program to seek the support of employers and community leaders through community sessions, home visits, and employer consent forms, rather than recruiting adolescent participants directly. This aspect of the program 
was mentioned numerous times and stood out as a very positive element. Association Tié also noted that they liked the well-structured and methodical approach of the Population Council, and the interactive nature of the curriculum.

\subsection{Program Implementation}

\section{Forming Program Partnerships}

One goal of the 2010 formative research was to identify organizations working with the target population in Ouagadougou and Bobo Dioulasso and select partners for this intervention. In Bobo Dioulasso, the Association Tié was selected as a potential partner, while in Ouagadougou, ADEP and ASMADE were identified as potential partners. Contract negotiations with the Association Tié and ASMADE were initiated in 2011.

\section{Partner training}

In September 2011, the Population Council held a four-day training for Association Tié and ASMADE. Three Association Tié and three ASMADE employees attended. The training covered background information on the targeted population, the reason for the choice of population and intervention, the objectives of the project, the tasks required of the implementing partners, foreseeable challenges, and an intense review of the curriculum.

Feedback from members of Association Tié indicated that four days was not an adequate amount of time for the training. They stated that they appreciated the content of the training and that it transmitted important knowledge about girls' vulnerability and that of the target population in particular. However, they suggested that the training be lengthened, and that more time be spent on understanding the structure of the program before moving into the actual

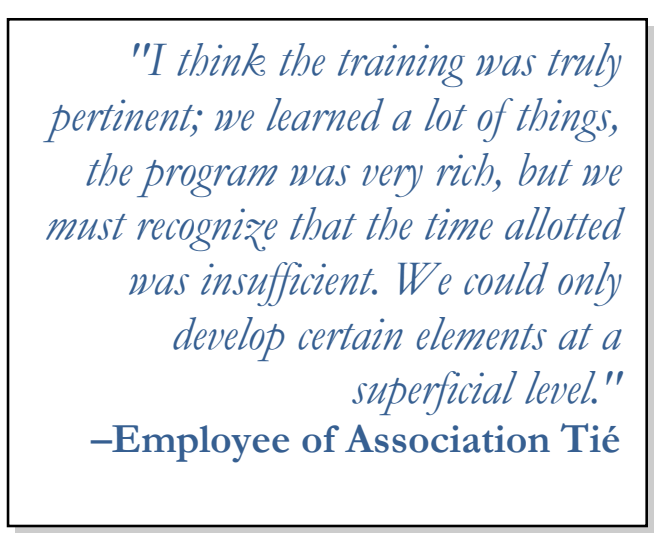
curriculum modules. Association Tié also suggested spending more time discussing the translation of key words and concepts from French to Dioula and Mooré.

\section{Ouagadougou partner}

When ASMADE was invited to be a partner in Filles Éveillées, they expressed interest in and availability to assume the project, and a contract was negotiated and signed. In September and October of 2011, ASMADE proceeded with their duties. They attended the partner training, selected sectors in which to hold the groups, recruited mentors, and held the mentor training. The mentors recruited participants for the program and baseline data for the quantitative study was collected from participants. In November, ASMADE indicated that they did not in fact have enough staff time to handle the project, and suggested hiring additional staff. The Population Council agreed to this, the budget was revised, and an additional staff member for ASMADE was hired. However, additional problems continued to arise, and in December 2011, after much negotiation and deliberation, it was jointly decided that ASMADE would not be able to proceed with 
implementing Filles Éveillées. No sessions were held for the girls' groups in Ouagadougou.

\section{Adjustments to the program in Bobo Dioulasso}

The late date of ASMADE's withdrawal in Ouagadougou meant that finding a replacement organization, negotiating a new contract, and holding a training for the organization would further delay the implementation of the planned groups. As an alternative solution, the Population Council decided to expand the contract with Association Tié in order to recruit an additional three groups of girls and three mentors in three additional sectors in Bobo Dioulasso. This was proposed to Association Tié and the Jacobs Foundation, and all parties agreed that this was the best solution. Recruitment of new mentors was followed by a three-day training and the program launch in the three new communities. In the interest of beginning sessions as soon as possible, some mentors initiated sessions before having 30 participants recruited for each group. Association Tié initially explored the possibility of holding two sessions per week (one Sunday and one Thursday) to make up for the later start of the sessions, but found that employers were unwilling to allow their employees to attend sessions more than once a week. As a result, two lessons were taught each Sunday, allowing the program to be completed in 15 weeks but requiring sessions to be two to three hours long. This presented its own set of challenges, as mentors reported that by the second lesson of the day the girls tended to be tired, distracted, and difficult to engage. However, given the less-than-ideal circumstances, this was a satisfactory solution for all involved and allowed the original target number of girls to participate in the program.

\section{Mentor recruitment and training}

Association Tié reported that they wished they had more time between the training they received and the launch of the program to allow for the recruitment and training of mentors. To assist in mentor recruitment, Association Tié hired a public announcer who broadcast the available positions over a loudspeaker mounted on a car in the relevant sectors. The organization invited candidates who fulfilled the age and education requirements to submit applications and resumes and to come for interviews. Six candidates applied, and three mentors and one alternative were selected. Association Tié was able to hire and train the mentors according to the predetermined schedule, but stated that they felt rushed.

Before beginning to recruit participants, mentors in Bobo Dioulasso were given a threeday training by Association Tié, in which they reviewed the objectives of the program, requirements for home visits (visites à domicile - VADs), community meetings, evaluation tools, and went through each lesson in the curriculum. Two separate trainings were held - one in October 2011 for the mentors for sectors 2, 4, and 9/10, and an additional training in March 2012 for mentors for sectors 8, 17, and 20. Mentors reported unanimously that while the content of the training was very good, the training itself was too short. Mentors expressed a desire to delve deeper into the curriculum, to learn 
teaching and mobilization techniques, and to discuss the explanation of key concepts in Dioula. Mentors suggested at least one more day of training.

\section{Relationship between mentors and Association Tié}

Overall, the relationship between mentors and Association Tié was reported to be positive. Mentors stated that Association Tié supported them when necessary in mitigating disputes between employers and participants and sometimes accompanied them on home visits. Mentors also reported that weekly meetings held after each session with Association Tié were helpful, and that Association Tié provided assistance in preparing mentors for the upcoming sessions, particularly issues with delivering the curriculum in Dioula.

However, there was one incident that, from the point of view of the mentor involved, required more responsiveness from Association Tié. The mentor in question received a call after a session ended stating that the adolescent domestic worker had not returned home. This resulted in several hours of searching for the girl, who was eventually found unhurt. The girl had decided with another program participant to

"If the employer wants to desist so that the girls don't come to the program anymore, and if we intervene and it doesn't work, we call the Association and they come to intervene and things go back to normal. In general when the person from the Association comes, it works." -Program mentor, Bobo Dioulasso run away to Ouagadougou, but plans had gone awry and the girl was spending the night in the street. The employer initially blamed the mentor for having incited the girl to run away, but the girl eventually admitted that it had been her friend's idea and not the mentor's. Though the situation was resolved, the mentor expressed displeasure in the fact that throughout this ordeal, she tried multiple times to contact members of Association Tié, none of whom responded until the following morning. Given that the sessions are held on Sundays, it is important for mentors to be able to contact program staff even on weekends, and for program staff to respond promptly and appropriately.

Home visits: Visites à domicile (VAD)

Mentors were expected to conduct at least three visits to the home of the employer of each participant over the eight months of the program, or more in the case of incidents or participant absences. Taking into account participant attrition and the fact that a few of the girls had the same employer, each mentor should have conducted a minimum of 75 90 visits.

The number of VADs varied greatly among mentors, with two mentors conducting only 17 VADs each and another conducting the full 90. Challenges to conducting VADs include absence or unavailability of employees, but this should not have resulted in such low numbers for some mentors. Overall VADs proved to be a valuable tool for encouraging employers to support the program. Mentors and participants reported that the VADs encouraged employers to allow participants to finish their work and arrive at the sessions 
on time. Employers reported that VADs made them take the program more seriously and helped them to keep up to date with what their employees were learning. Mentors also stated that there were several times in which VADs facilitated conflict resolution between employee and employer. When mentors were unable to solve conflicts, members of Association Tié sometimes accompanied them on VADs, which mentors reported to be one of the most helpful types of support they received from Tié.

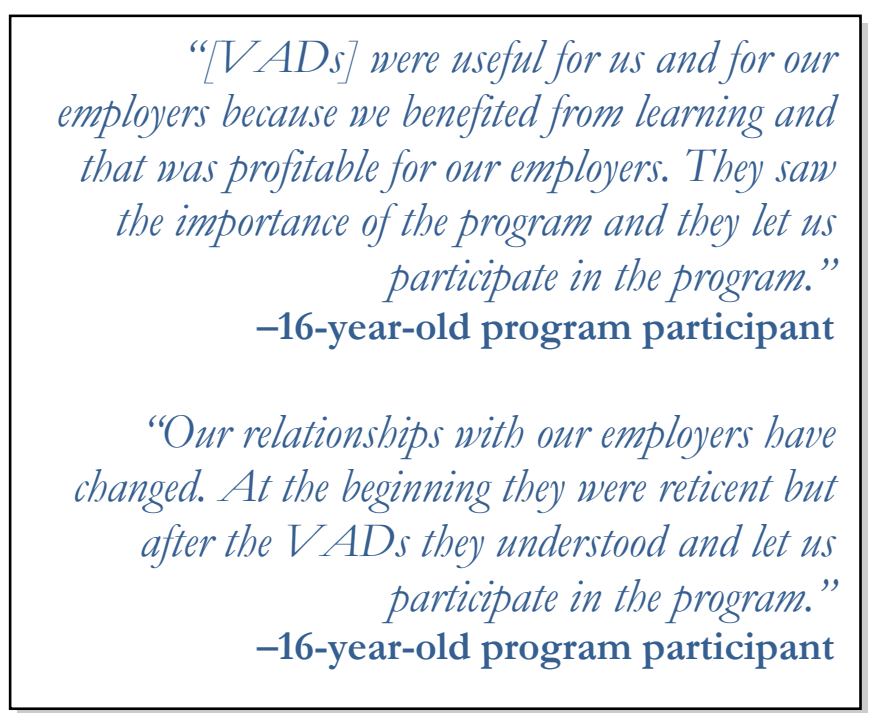

\section{Safe spaces and program logistics}

Overall, Association Tié and mentors reported that the concept of safe spaces was a useful concept and that it worked well. Verbal agreements were made with the community and/or those in charge of the space in order to ensure the accessibility of the space for the duration of the program. The safe spaces were researched and selected by the implementing organization, and their use was negotiated with community leaders and/or the owners of the space. Churches, mosques, and other religious spaces were avoided in order to keep from associating the program with a religion and potentially alienating some of the participants. In Bobo Dioulasso, two safe spaces were primary schools and one was a preschool. Another space was a meeting room in a facility owned by the Ministry of Social Action, and a fifth space was owned by a local NGO that works with vulnerable children. The last space was a courtyard where mangos are dried for sale. Three of the spaces required benches to be built while three already had adequate seating. Three of the spaces were enclosed, while the other three had roofs for shelter but were outside spaces with no walls. Some logistical issues were presented by the specific safe spaces used. For example, the open spaces presented problems when it rained and was windy because it was difficult to hear and girls got wet. The mentor from Sector 20 stated that her space, the courtyard for drying mangos, was too isolated. Several lessons in the curriculum also require the mentor to hang sheets of paper on the walls, which was impossible in some of the spaces.

Mentors also mentioned that for exercises requiring the use of FCFA (Union Économique et Monétaire Ouest Africaine [UEMOA] currency, used in Burkina Faso) bills and coins in the financial capabilities section, they did not have the money at their disposal. The curriculum called for the use of fake bills, but these are illegal to produce in Burkina Faso and would also not be very useful given that the majority of the girls are illiterate. Real bills and coins would be more appropriate, as even illiterate participants can recognize the value of the currency based on color and size of the bills and coins, which provides them with more applicable knowledge. 


\subsection{Program Structure}

\section{Session scheduling}

The day and time chosen for the meetings was based on formative research and was designed to be on the day of the week where the most participants would be able to attend, during the months when the majority of girls would be in the city. Some employers reported that Sundays were difficult because there is a lot of housework to be done on weekends, but for most Sunday afternoon continues to be the best time.

Many participants stated that eight months was not long enough, and some participants who did the accelerated program stated that they would like to complete the program again. Participants did not, however, state that this was based on an inability to understand the lessons, but rather that they enjoyed the program and wanted it to continue. Given the mobility of the target population that is not possible, but it is encouraging to know that the participants enjoyed it enough to want to do it again or to continue. In 2012, the rainy season started slightly earlier than normal, causing many girls to migrate to their villages of origin earlier than in other years. In addition, the timing of the program caused the girls who enrolled in cours du soir to miss the beginning of these classes (discussed in further detail below).

\section{Program attendance}

On average, participants in Filles Éveillées attended 22 out of 30 sessions. Out of 178 program participants, 128 participants (72\%) attended at least 20 of the sessions, including 33 girls (19\%) who attended every single session. The main obstacles to consistent attendance were participants having too much work to do or employers giving participants tasks right before the allotted time for the session. Mentors often made home visits when girls missed sessions in order to find out the reason for the girl's absence and to attempt to sensitize employers to the importance of the girls coming to every session. Other reasons for absence included illness, and events or emergencies in the employer's family such as a wedding or a death. In some cases, mentors were unable to find out the reason for the absence.

An additional problem was tardiness to sessions. This interrupted the flow of the sessions and sometimes required re-explaining concepts for girls who arrived late. All mentors reported that there were consistently at least a few girls late to each session. Reasons for this included the amount of work the participants had and employers assigning tasks right before the allotted time for the session.

Reasons for program attrition included having too much work or being restricted by the employer, returning to the village of origin, or in one case, a girl dropped out of the program when she gave birth to a child. Forty-seven girls began the program but abandoned it at least one month before completing it, including 31 who dropped out halfway through or earlier. 
Mentors

Participants reported very positive relationships with their mentors. During focus group discussions, participants said that they considered their mentors like friends, went to them for advice, and felt comfortable asking them questions. Mentors also reported that participants sought them out for advice on a variety of subjects such as marriage and relationships with employers. Participants suggested that the most important characteristics of a good mentor are that she be discrete, trustworthy, attentive, polite, and welcoming.

\begin{tabular}{|} 
"When I started to work at the \\
beginning, I had a lot of disputes with my \\
employer and I wanted to leave my job, \\
but thanks to the mentor I decided to \\
stay, because her advice was helpful." \\
-16-year-old program participant \\
"It's because we feel comfortable with \\
[our mentor] that we come and tell her \\
what we think. With her, there's more \\
security in communicating - you consider \\
her like a friend." \\
-15-year-old program participant
\end{tabular}

\section{Participants' friendships}

Mentors, participants, and the Association Tié all noted that the program participants in each sector formed strong friendships and that this was a benefit of the program. Mentors commented that adolescent migrant domestic workers do not otherwise have the opportunity to form friendships while working for their employers, and participants themselves remarked that their groups had become like families.

\section{Target age groups}

For the first three groups, in sectors 2, 4, and

"If a girl is sick or has lost a
relative, we visit her."
-14-year-old program participant
"If there's a marriage or a baptism,
we all chip in and give something to
the person, we're like a family."
-15-year-old program participant
9/10, the groups consisted of participants ranging in age from 11 to 16 . In ongoing feedback, mentors stated that younger girls in their sessions sometimes had a hard time understanding lessons and had difficulty relating to the older girls on lessons about subjects such as sexuality. As a result, the Population Council decided to experiment with a different group construction for the fourth, fifth, and sixth groups, in sectors 8, 17, and 20. The age range was smaller, with two groups consisting of participants aged 14 to 16 and one group with participants ages 11 to 13. However, the mentor for the youngest group of participants, aged 11 to 13, reported similar difficulties with comprehension and with engaging the youngest girls in the subject matter, and separating the younger girls did not appear to have helped remedy the problem. Association Tié also reported that finding and recruiting a sufficient number of girls of these more specific age groups was difficult, particularly for the younger (11-13) cohort. Opinions of mentors differed on whether or not it is advisable to divide groups according to age. 
Providing a meal to the participants at the end of each session proved to be an important part of the program. In similar programs piloted by the Population Council in other settings, providing food to participants has not been practiced. However, formative research showed that virtually all programs in Burkina Faso targeting the same population do provide food. Given their level of poverty, the girls often do not have another means to obtain a full meal on the day of the session, particularly if attending the session causes them to miss a meal at their employer's house. As a result, it was deemed to be an important element of the program.

\section{Program closure}

During the first year of the program, no party or ceremony was planned to recognize the participants at the completion of the curriculum. Several of the girls found this disappointing and complained about the abrupt ending to the program. Mentors, participants, and employers all suggested having some sort of ceremony or party to finish the program.

\section{Literacy courses and " cours du soir"}

Out of the initial 90 girls enrolled in the first three groups of Filles Éveillées, 59 girls enrolled in the cours $d u$ soir. Their enrollment and tuition fees were covered by the program Filles Éveillées with funding from the Population Council. Of these, 39 girls enrolled at a basic level, the equivalent of $1^{\text {st }}$ grade. Forty-two girls (71\%) earned adequate grades to pass on to the next grade level, while 11 girls dropped out of the cours $d u$ soir. The overall average grade was 5.12/10.

The initial justification for offering the literacy courses as opposed to cours $d u$ soir was that the participants could complete the literacy course in the time of the program, whereas the cours du soir takes years to complete if one is starting at an elementary level. The girls who enrolled in the cours du soir and have done well want to continue with their education, but are unable to without continued funding from Population Council. A decision has been made to continue to pay the school fees for the girls who have completed Filles Éveillées, but this is only possible until the end of the next academic year in 2013. Therefore, girls who enrolled in the first cohort of Filles Éveillées will have the opportunity to complete two years of school. The Population Council is not an institution that normally provides funding for education for individuals, nor was funding originally set aside for this purpose within the scope of Filles Éveillées.

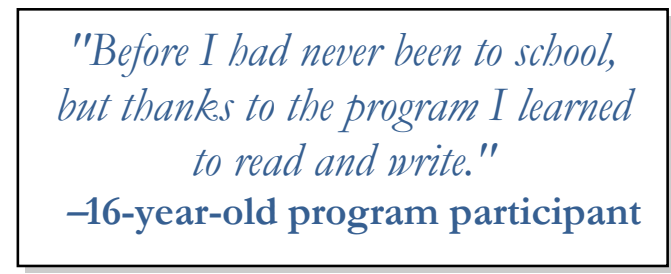

It is worth noting that even upon completion of a year of schooling, girls are unable to receive a certificate of completion of any kind unless they have a birth certificate or other official identification, which most of the girls do not. It is possible to obtain these documents, but it is necessary for a relative and a witness to be present, and often must 
occur in the village of origin. Because there is no verification of identity or age before creating program ID cards, these cannot be used in an official capacity.

A final challenge was presented by the fact that girls were unable to enroll until January and therefore missed as significant number of classes at the beginning of the year. This was because the cours du soir began before Filles Éveillées sessions began, and participants were unable to enroll mid-semester. For the next cohort, girls should be asked about their interest in cours $d u$ soir

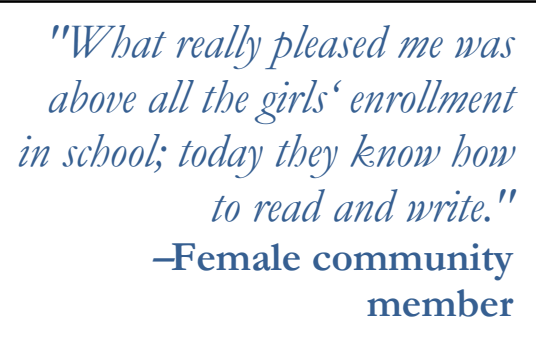

"What really pleased me was in school; today they know how to read and write" to read and write." member during recruitment so that participants are able to enroll as soon as classes begin.

Some employers were reluctant to allow their employees to participate, or doubted that the girls would attend the course consistently. Home visits to speak with employers as well as visits to the schools by mentors, employers, and members of Association Tié alleviated employers' concerns and confirmed that overall the participants were committed to the cours du soir. Teachers commented that the girls worked hard and participated in class. In general the girls received good grades and several participants cited the opportunity to enroll in school as being one of their favorite things about Filles Éveillées. Employers expressed pleasure as well in seeing the girls have the opportunity to learn to read and write.

\subsection{Curriculum}

Overall, the curriculum was deemed to be well-organized and relevant to the needs of the participants. One member of Association Tié commented in particular that he appreciated the interactive nature of the curriculum and that this helped engage the participants. Mentors stated that they found the role-plays, examples, and stories to be particularly helpful in engaging participants. All of the participants in the focus group discussions could mention two or three things that they learned as a result of program participation. Several mentioned knowing how to save money, several mentioned knowing how to avoid pregnancy and protect themselves from STIs, and several mentioned knowing how to wash their hands and keep clean. Conversations with mentors and participants also revealed several ways in which the curriculum can be improved, and this advice is being incorporated into a curriculum revision that is taking place in the third quarter of 2012.

\begin{tabular}{|} 
"As we say in Africa, 'an educated girl \\
is an educated nation.' This knowledge \\
that [the girls] will acquire will not be \\
just for them but for everyone. They will \\
pass it on to their sisters, brothers, \\
neighbors, friends, and even to their \\
children when they are in their home." \\
-Male community member
\end{tabular}

"As we say in Africa, 'an educated girl is an educated nation.' This knowledge just for them but for everyone. They will pass it on to their sisters, brothers, neighbors, friends, and even to their -Male community member

\section{Relevance of program content}

Employers, mentors, and participants all stated that the content of the curriculum was relevant for the target population. All four modules were cited by different participants as 
being favorites. Individual lessons listed as most useful included those covering pregnancy, STIs, HIV, reproductive health, illnesses, and hygiene, among others. Employers, community members, and participants all mentioned hygiene various times as having been particularly useful, and several girls commented that they didn't wash their hands after using the toilet before, but that now they do.

"She changed physically in terms of bygiene and I noticed that after using the toilet, she washes her hands, she's become very clean. And then she shares her knowledge about diseases and HIV with my daughters. That really pleased me, plus she respects people and she's always polite." -Employer sector 4

\section{Language}

Sessions in Bobo Dioulasso were conducted in Dioula, and sessions in Ouagadougou will be conducted in Mooré, as the majority of the participants do not speak French. Mentors reported that several of the concepts were difficult to explain in Dioula. Part of this was due to a lack of some key words which were not translated into Dioula, or for which the translation was not exact. The list of key words in Dioula and Mooré was translated by a professional translator, using the respective alphabets. However, the mentors themselves were generally not literate in Dioula or Mooré, as French is the primary language used in formal education. Therefore, the mentors would prefer that the list be printed in "francoDioula," using the French alphabet, with which the mentors are more familiar. Lastly, there was a problem when printing the curriculum with the glossary of key words in the back, resulting in letters with accents or symbols being printed as blank boxes. This made many of the words which had been translated unreadable for the mentors.

\section{Literacy}

An additional problem is posed by the fact that the majority of girls in the program are illiterate. Curriculum development avoided literacy-dependent activities for the most part, but some exercises borrowed from other curricula require that the mentor make lists on flip charts or ask girls to write or draw something, of which the girls are incapable. This is a primary focus of curriculum revision.

\section{Content}

Certain lessons, particularly those regarding the menstrual cycle, reproductive health, and sexuality, were found to be overly technical and difficult for the girls to understand. It is suggested that these lessons (specifically lessons 16, 17 and 19-22) be simplified in order to ensure understanding of key facts (such as how to protect oneself from pregnancy and STIs, when one is most likely to become pregnant, what one should do in the case of sexual assault or unwanted pregnancy, etc). Additionally, themes regarding reproduction and sexuality were difficult for some of the younger girls to relate to. Module 1, on Life Skills, was cited by some as being too philosophical, difficult to translate, and difficult for the girls to grasp. However, few suggestions were made by mentors or program officers as to how to revise the content to make it easier to teach. Module 4, 
Financial Capabilities, was cited by several mentors as being a clear, easy module to teach.

\section{Curriculum support}

For lessons with technical health information, mentors suggested inviting a nurse or health worker to assist, such as during session 17 ("Reproduction and the male and female reproductive systems"), as well as to speak during session 15 ("The use of health services by adolescents"). A nurse's presence for session 15 is currently specified in the curriculum, but did not occur for any of the groups.

\section{Additional subjects}

Additional subjects that girls expressed interest in were forced marriage, newborn care, more detail on childbirth, and le levirate, a practice in which a widow is obligated to marry her deceased husband's brother or other family member. Forced marriage was most frequently cited as an additional topic of interest. The eight months of the program, however, were as aforementioned based on formative research determining the seasonal availability of the participants, and it is not feasible to add additional sessions, nor should the program stray from its original goals. The participants stated that all sessions were useful and did not suggest any for omission.

\subsection{Community Engagement}

\section{Engaging employers}

Employers and mentors stated that home visits were most helpful in garnering their participation and encouraging them to allow their employees to participate. Community members also emphasized the importance of community leaders' support of the program, and their presence at community sessions.

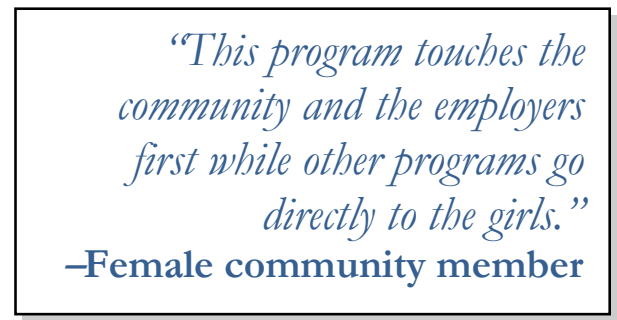

\section{Community sessions}

Community sessions were held throughout the program in each sector. A grand total of 15 community sessions were held between October 2011 and June 2012. For the original three sectors - sectors 2, 4, and 9 - three initial community sessions were held in October 2011 (one session in each sector), three additional sessions followed in April and May, and three final sessions were held in June. For the cohort of sectors which started later - sectors 8, 17, and 20 - three initial sessions were held in March 2012,

"At the beginning my employer was against it. But the fact that I got to the end of the program was my biggest challenge; I was able with the help of my mentor to bring my employer to accept the program." -12-year-old program participant and three more in June 2012. For the October community sessions, public announcements were made via a loudspeaker on the back of a taxi that drove through the relevant sectors, and public announcers and mentors also went door to door to announce the meetings. For later 
sessions, community leaders made announcements, and in Sector 4, a community leader also provided chairs and benches as well as water for attendees.

An estimated 100-150 people attended each of the October sessions, 250-400 people attended each of the March sessions, and over 400 people attended each of the June sessions. It is hoped that the increasing number of attendees as well as the contribution of a community leader in sector 4 shows an increasing level of commitment to the program.

Each of the sessions featured Association Tié staff and mentors who described the content of the program and any upcoming events (such as the arrival of the surveyors for data collection), participants who testified as to the importance of the program, employer testimonials, and an allotted time for the public to ask questions. Some of the sessions also featured musical performances or a dance performance by a local group. In addition to testimonials from program participants and employers, the Population Council had recommended that participants perform role-plays demonstrating some of the skills they had learned. This was not carried out.

"The community sessions permitted the
population to know that there are
children like domestic employees who
also have rights we should respect. They
also permitted certain people from
society to see how Population Council
intervenes through Association Tie and
the leaders are very involved in the
program, especially the religious and
traditional leaders. The association
really involved the people."
-Male community member

The community sessions permitted the children like domestic employees who so have rights we should respect. The also permitted certain people from society to see how Population Council intervenes through Association Tié and the leaders are very involued in the program, especially the religious and really involved the people."

-Male community member

\section{Community contribution}

During focus group discussions on potential contributions that the community could make to the program, one community member suggested that the community may be able to provide the use of benches as well as safe spaces for Filles Éveillées, while others expressed the belief that the program should provide all necessary materials. Others said that the community contribution is simply letting the girls participate, and convincing other employers to let their employees participate. This topic is being explored in greater detail for the next cohort.

\section{Engaging former program participants}

Girls who have completed the program said that they could see themselves playing a role as assistant to the mentors, recruiters for other girls, and models in the community. They offered to orient other girls about the program in order to encourage enrollment. Employers and mentors suggested similar roles for girls who have completed Filles Eveillées and also suggested that the girls work as intermediaries between the program and the community or as program representatives. For example, one mentor suggested that the some girls be featured in a radio or television ad for the program, and this suggestion was echoed by a

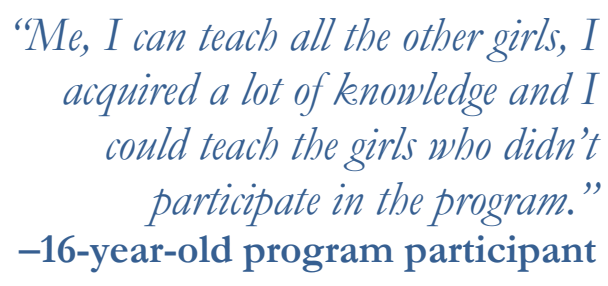
acquired a lot of knowledge and I could teach the girls who didn't participate in the program." -16-year-old program participant 
community member who emphasized the importance of media in spreading the word about the program.

Participants expressed that they plan to share the information and skills they have learned with sisters and friends when they return to their villages. Participants also stated that they will tell friends and family about the program in their village, and encourage girls from their villages who plan to migrate to enroll in the program as well. In other similar programs, the Population Council has implemented a cascading leadership model, where program participants can go on to become program leaders, though this model would be especially difficult with a highly mobile population and therefore was not built into the design of Filles Éveillées.

\section{RECOMMENDATIONS AND SUBSEQUENT CHANGES²}

\subsection{Program Implementation}

For the 2012-2013 program, the feedback from implementing associations and mentors regarding the length of their respective trainings should be taken into account and training should be lengthened. For implementing organizations, the training will be five days long and for new mentors, the training will be four days, with a three-day refresher for mentors who have previously conducted the program.

With regard to the insufficient number of VADs conducted by some mentors, a new monitoring and evaluation tool has been developed to more efficiently keep track of how many VADs each program participant has received. Additionally, implementing organizations have been instructed to routinely check in with mentors about VADs during their weekly work meetings, and a reference to VADS has been added to that monitoring and evaluation tool. Because part of the purpose of this grant is to develop organizational capacity, further guidance will be offered to implementing organizations to assist with effective supervision of mentors. Other monitoring and evaluation tools which have been added for the implementing organizations to complete include a summary of community awareness sessions, a summary table of participants' progress in the cours $d u$ soir, a summary of weekly work meetings with mentors, and two tools regarding assistance given to participants in cases of special need, such as pregnancy or illness.

\subsection{Program Structure}

Several parts of the program structure worked very well and should be continued as they were. The mentor model, successfully implemented in other contexts as well, has proven to be well adapted to the Burkina context and should be continued. Food provided to participants at the end of each session was deemed an important part of the program and should also be continued. The scheduling of the program on Sunday afternoons should remain in place, as this was shown to be the most convenient time for participants and employers.

\footnotetext{
2 Some of the changes outlined in this section have already taken place as of the finalization of this Process Evaluation. Others are planned or underway.
} 
In order to show appreciation for the participants who have committed their Sunday afternoons to attending Filles Éveillées, it is suggested the third and last community session in each sector in 2013 incorporate a small ceremony of recognition. This should include certificates of participation for girls who participated in the program and certificates of merit for those who had high attendance rates (attended at least 20 sessions). Having a document from the program could also aid the girls in finding future employment.

With regard to the problem of the cours du soir versus literacy courses, one possibility is to find an alternative source of funding which the girls can use through an alternative structure after they finish Filles Éveillées. A second possibility is to offer only the literacy course, which can be completed in the eight months of the program, but which is deemed by the participants to be less useful. As such, fewer participants may enroll and it may be less advantageous for those who do enroll. A third, less desirable possibility is to offer no educational funding opportunities at all. It is recommended that for the incoming cohort, the opportunity to enroll in the cours $d u$ soir be given, and it should continue to be made clear to participants that this funding support will not be continued beyond the end of Filles Éveillées. Instead, the implementing partners should seek out alternative institutions which can provide ongoing funding for education for girls who want to continue taking classes. For example, ADEP itself provides such funding for some students. To facilitate advancement in classes and the obtaining of certificates of completion, participants should be guided and encouraged by mentors to seek legal documents with the help of family when visiting their villages. A short exercise explaining the importance of an official document and how to obtain one has been added to the first session of the curriculum, and mentors should provide guidance as needed.

After discussions with mentors, Association Tié, and the Population Council, it was decided that the age range should remain the same: 11-16 years in Bobo Dioulasso and 15-18 years in Ouagadougou, and that groups in Bobo should not be split according to age. While some of the younger girls had difficulty in understanding some of the lessons, this was not resolved by splitting younger girls into a separate group. Rather, revisions to the curriculum should focus on increasing accessibility for girls in the entire age range.

\subsection{Curriculum}

The feedback collected for the Process Evaluation allowed significant targeted revisions to be made to the curriculum in terms of content, organization, and extra resources in the third quarter of 2012. The primary concern with the curriculum expressed by mentors and implementing partners was the curriculum's adaptation to the targeted population, taking into account their age and their illiteracy. As a result, all exercises requiring reading or writing have been altered to accommodate illiterate participants. There are no longer any exercises in the curriculum which require participants themselves to read or write, and mentors are reminded to always read aloud whatever is written on flip charts. Alternative options for exercises in Sessions 29 and 30 have been added in case the already- 
simplified activities are still too complicated. More visual resources have been added to sessions 18 and 23, and the curriculum now calls for actual samples of different forms of contraceptives to be shown to participants in session 24. Session 13 was found to contain too much information for the girls to retain; therefore the amount of information has been reduced and the information itself has been simplified.

Furthermore, certain exercises have been altered to make it easier for younger girls who are not yet sexually active and may not have entered puberty to understand, particularly sessions 22 and 23. These two sessions were also reordered to give the girls a basic understanding of puberty and reproductive organs before moving on to menstruation, ovulation, and reproduction. It is hoped that these additional visuals, simpler language, less information, and more examples will facilitate comprehension. Mentors also suggested increasing the allotted time for these lessons to 90 minutes, which was also done. Vignettes and examples were also added to sessions 6 and 7 in order to better illustrate abstract ideas such as values and self-affirmation.

The module on financial capability assists the participants in learning how to save money and set savings goals. In order to increase the impact of the module on financial literacy, this module has been moved and is now the second module in the curriculum rather than the last. In this way girls can be encouraged over the course of the program to exercise their skills in saving, and mentors can monitor their progress. A monitoring and evaluation tool to keep track of participants' savings goals has been developed as well. With regard to the issue of fake bills versus real money to use for exercises, the organization in charge of the program should provide this money to the mentors out of the program funds given to them by the Population Council. Since the mentors can sign the money out, use it for the exercises, and return it to the organization after the exercise, there is no need for extra money to be budgeted to implement this module of the curriculum.

Though the constraints of a 30 week time period prohibit adding more sessions, some exercises can be added to sessions which were already short and simple. For example, in light of both the success and the relative simplicity of the session on corporal hygiene, an activity to teach dental hygiene has been added, as this can have a significant impact on ones' diet and health, and the health of the participants' current or future children.

In terms of language, the printing issue which resulted in illegible Dioula and Mooré words has been resolved. An additional resource with "franco-Dioula" and "franco-Mooré" spelling in order to facilitate pronunciation should be provided to mentors.

At least one visit by a nurse was suggested in the previous curriculum, but no group was able to benefit from such a visit. It is suggested that the organization in charge of implementing the program make the necessary arrangements several weeks in advance, and, if necessary, have a back-up nurse or a back-up session planned in order to ensure that the participants are given the opportunity to get the information they need. Additional 
reminders and specifics for preparation have been added to the curriculum in order to encourage adequate advance planning. The Population Council will hold the implementing organizations accountable to ensure that these visits do take place. Another suggestion is to include a group excursion to a health center so that the girls can also be familiarized with the location. In sector 8, participants expressed interest in getting tested for HIV and requested the mentor's help in doing so. Leading a group excursion could alleviate apprehension about going alone and encourage girls to use the services available, for HIV testing or for other services. An activity involving the visit of a person from a local bank has also been added to session 13, and similar advance planning will be required.

\subsection{Community Engagement}

Efforts to engage the community were overall very successful, and home visits and community sessions were widely appreciated and should be continued. Community leaders should continue to be approached and encouraged to contribute in whatever way they can, whether this be the contribution of the safe space, of benches for use during the meetings, or of chairs or refreshments during community sessions. The example of the community leader from Sector 4 who provided benches and water could be evoked and may inspire others to more actively support the program. Association Tié has met with multiple community leaders in the third quarter of 2012 to discuss their possible contribution to the program. In order to make the community sessions more interactive and engaging, it is suggested that girls perform skits or role-plays to demonstrate what they have learned. In addition, it has been decided that in Bobo Dioulasso, Association Tié and mentors will hold small discussion groups with employers to garner support and strengthen relations between employers and the Filles Éveillées program.

For program graduates, the Population Council plans to develop a resource of relevant visuals and support the implementing partners in training interested participants to pass on their knowledge to peers and others in their communities and in their villages. The development of a resource for graduates to use will need to take into account the fact that most program participants are illiterate.

\section{CONCLUSION}

Findings from quantitative and qualitative data collection have shown Filles Éveillées to be a very successful program that has been greatly appreciated and well-received by participants, mentors, community members, and all other stakeholders. As a pilot program, it is inevitable that there will be obstacles to smooth implementation, as there were with Filles Éveillées. However, the hard work and responsiveness of Association Tié, the Population Council, and the Jacobs Foundation allowed the target number of girls to be reached and for the program to be implemented as planned. This first cohort allowed the opportunity to test the program model in order to improve it, and several adjustments have been made accordingly. An impact evaluation conducted in 2013 will reveal to what extent the program has succeeded in its objectives of reducing vulnerability and increasing opportunities for this highly vulnerable population. It is hoped that the results 
of the Process Evaluation and the corresponding adjustments to the program will help make these objectives a reality. 


\section{REFERENCES}

Population Council. (2012a). Developing Capacity for Targeted, Evidence-based Programming and Asset Building for Adolescent Girls. Retrieved September 28, 2012, from Population Council. http://popcouncil.org/ projects/164_DevCapProgramAdolGirls.asp\#/jQueryUITabs1-1

Population Council. (2012b). Burkina Faso: Overview. Retrieved July 22, 2012, from Population Council: http://popcouncil.org/countries/burkinafaso.asp

Population Council. (2012c). Who We Are: Overview. Retrieved July 22, 2012, from Population Council: http://popcouncil.org/who/index.asp

Population Council. (2009). The Adolescent Experience In-Depth: Using Data to Identify and Reach the Most Vulnerable Young People: Burkina Faso 2003. New York: Population Council.

Population Council; Guttmacher Institute. (2010, June 14). Atteindre les Adolescents Qui ont les Plus Grands Besoins: Le Cas du Burkina Faso. Ouagadougou, Burkina Faso.

Population Reference Bureau. (2011). World Population Data Sheet. Retrieved July 22, 2012, from Population Reference Bureau: http://www.prb.org/pdf11/2011population-data-sheet_eng.pdf

United Nations Development Programme. (2011). Burkina Faso Country Profile. Retrieved August 10, 2012, from International Human Development Indicators: http://hdrstats.undp.org/en/countries/profiles/BFA.html 


\section{ANNEX 1: QUALITATIVE DATA COLLECTION TOOLS}

\subsection{Guide de Discussion de Groupe avec les Mentors}

Bonjour, et merci pour avoir accepté de participer à la discussion de groupe avec les autres mentors pour le programme "Filles Éveillées". Je suis et je suis ici pour apprendre un peu plus sur ce que vous pensez sur le programme et comment on pourrait l'améliorer. On voudrait avoir toutes vos idées et aussi vos critiques positives ou négatives. N'hésitez pas à me dire aussi les choses négatives parce qu'on veut savoir aussi ce qui n'a pas marché pour améliorer lors de la deuxième phase du programme.

1. Est-ce que chacune de vous peut nous donner son nom et une chose que vous aimez plus dans le rôle du mentor?

Questions sur la formation (mise en œuvre du programme) : On va commencer avec des questions sur votre formation. Avant de commencer le programme, vous avez participé à une formation de trois jours animée par les chargés de programme de l'Association Tié. II y a 4 domaines ciblés par le programme "Filles Éveillées ": les compétences de vie courante, la santé et l'hygiène, la santé de la reproduction, et les capacités financières.

2. Qu'est-ce que vous pensez de la durée, la structure, le contenu, les approches utilisées par les formateurs pour le transfert des connaissances et la qualité de la formation ? Si c'est à refaire, qu'est-ce que vous ajouteriez à la formation pour vous permettre de mieux comprendre les objectifs globaux du projet?

3. Dans quel module êtes-vous le plus à l'aise et le plus préparée à enseigner ? Dans quel module êtes-vous le moins à l'aise et avez-vous le plus de difficultés à enseigner?

4. Qu'est-ce que vous ajouteriez à la formation pour vous permettre de mieux comprendre et enseigner les 4 domaines ?

5. Comment est-ce que le soutien de l'Association Tié vous aidait à répondre aux défis rencontrés tout au long du programme? Quel type de soutien était le plus utile pour vous?

6. Quelles suggestions précises faites-vous pour améliorer la formation des mentors et/ou le soutien des mentors par les chargés de programme de Tié tout au long du programme?

Contenu : Maintenant je vais vous poser des questions sur le curriculum du programme.

7. Est-ce que les exercices, les histoires de vie et les jeux de rôle utilisés dans le curriculum sont adaptés à la réalité des filles dans le programme ? Quelles stratégies vous a semblé la plus efficace pour engager/intéresser les filles à la session?

8. Qu'est-ce que vous pensez de la pertinence des quatre thèmes abordés par le programme pour la tranche d'âge ciblée dans "Filles Éveillées " (11-16 ans)? Est-ce que les filles ont manifesté l'intérêt pour d'autres thèmes ? Lesquels ? Et qu'est-ce qu'elles souhaiteraient exactement connaitre en plus des thèmes qui sont déjà abordés dans le curriculum? 
Structure : Maintenant je vais vous poser des questions sur la structure du programme.

9. Qu'est-ce que vous avez pensé de la structure d'utiliser un espace sûr, d'avoir des amies filles, et un mentor? Quels sont les avantages de cette structure? Quels sont les inconvénients?

10. Comment cela se distingue des approches d'autres programmes qui ciblent aussi les employées de maison?

11. Qu'est-ce qui fera le guide des mentors plus complet? (Considérez le niveau d'instruction pour la population ciblée, la variété des activités, les mots clés en fin du curriculum, les visites des personnes ressources dans la communauté, et les outils pour les mentors). Merci de signaler 2-3 choses dans le guide du mentor ou même de la structure du curriculum que vous souhaiterez changer avant de lancer ce programme pour la seconde cohorte.

12. Qu'est-ce que vous avez pensé de la durée de huit mois, une fois par semaine, et d'environ 90 minutes pour chaque session? Avez-vous eu suffisamment de temps pour animer les sessions et engager les filles?

13. Certaines d'entre vous ont travaillé avec des filles très jeunes (11-13 ans), d'autres avec des filles plus âgées (14-16 ans) et d'autres encore avec des filles dont l'intervalle d'âge est plus grand (11-16 ans). Quels étaient les avantages et les inconvénients/difficultés liés à chaque modèle?

14. Est-ce que les employeurs semblent être engagés pour le programme ? Est-ce qu'ils ont suivi le programme et parlent-ils souvent avec les filles sur ce qu'elles apprennent lors des sessions?

15. Qu'est-ce qu'on peut faire pour rendre les visites à domiciles plus utiles afin de gagner le soutien des employeurs et aborder les problèmes rencontrés par les filles de façon plus efficace?

16. Quelle était le plus grand défi pour vous dans le programme " Filles Éveillées "?

\section{Future}

17. Quel rôle voyez-vous pour les filles qui ont déjà terminé le programme et qui seront à Bobo lors de la deuxième phase? Par exemple, comme assistant au mentor? Recruteuse ? Intermédiaire avec la communauté ?

18. Quel rôle voyez-vous pour les filles qui ont déjà terminé le programme et qui vont rester dans leur village d'origine définitivement?

19. Selon vous comment le programme pourrait engager davantage les employeurs et les communautés?

Fin

20. Avez-vous quelques autres commentaires ou suggestions? 


\subsection{Guide de Discussion de Groupe pour les Chargés de Programme au Niveau de Tié}

Bonjour, et merci pour avoir accepté de participer à la discussion de groupe avec les autres personnes chargés du programme "Filles Éveillées". Je suis et je suis ici pour apprendre un peu plus sur ce que vous pensez sur le programme et comment on pourrait l'améliorer. On voudrait avoir toutes vos idées et aussi vos critiques positives ou négatives. N'hésitez pas à me dire aussi les choses négatives parce qu'on veut savoir aussi ce qui n'a pas marché pour améliorer lors de la deuxième phase du programme.

1. Est-ce que chacun de vous peut nous dire son nom et son rôle dans l'Association Tié et dans le programme "Filles Éveillées "? Qu'est-ce que chacun de vous fait exactement dans le programme?

Questions sur la mise en œuvre du programme : Avant de commencer le programme "Filles Éveillées", vous avez reçu une formation de 4 jours du Population Council en septembre 2011 sur les objectifs et la structure du programme, le lancement et les outils de suivi-évaluation, etc., et tout au long du programme vous avez reçu également leur feedback et soutien soit à travers les conversations hebdomadaires ou les visites de terrain.

2. Qu'est-ce que vous pensez de la durée, la structure, et la qualité de la formation ? Qu'est-ce que vous ajouteriezà la formation pour vous permettre de mieux comprendre les objectifs globaux du projet ou les attentes précises de votre rôle dans le projet?

3. Quelles sont 2 ou 3 choses que vous avez apprises au cours de cette formation ? Quelle était la chose la plus utile pour vous?

4. Vous avez reçu du feedback du Council tout au long du programme (à travers des visites sur le terrain, les appels hebdomadaires, le feedback sur les documents écrits). Quel type de feedback était le plus utile ? Comment est-ce que le Council pourrait mieux soutenir l'Association Tié, ou collaborer avec vous pour avoir plus d'impacts?

5. En général, quel exploitation faites-vous des outils de suivi-évaluation remplis? Comment avez vous utilisé l'information que vous avez reçue sur les outils de suiviévaluation pour surveiller les progrès du programme et réajuster des choses en fonction des données? Citer 2 ou 3 exemples.

6. Quel outil était le plus utile? Quel outil était le moins utile? Pensez-vous que vous avez les outils nécessaires pour renseigner le programme ou bien il y a des outils qui manquent et qu'il serait nécessaire de les développer? Si oui, pour renseigner quelle activité ?

7. Qu'est-ce que vous pensez des canevas des rapports narratifs que vous remplissez? Pensez-vous qu'on doit changer le format? Si oui, comment?

8. Quels types de soutien apportez-vous aux mentors? (Demandez-leur les comptes rendus de réunion avec les mentors pour apprécier le contenu.)

9. Quels types de soutien est-ce que les mentors ont cherché auprès de l'Association Tié? Vous vous sentiez bien préparés pour répondre à leurs questions? 


\section{Structure}

10. Qu'est-ce que vous pensez de la structure d'utiliser un espace sur, un groupe de filles, et un mentor? Quels sont les avantages de cette structure? Quels sont les inconvénients? Comment cela se distingue des approches d'autres programmes ciblant les filles domestiques?

11. Qu'est-ce que vous pensez de la durée de huit mois, une fois par semaine, et d'environ 90 minutes pour chaque session?

12. Après vos visites au programme et vos discussions avec les mentors, qu'est-ce qu'on pourrait faire pour améliorer l'approche de "Filles Éveillées" pour mieux aborder les défis que les filles migrantes rencontrent?

\section{Contenu}

13. Qu'est-ce que vous pensez de l'alphabétisation/cours du soir des filles? Considérez I'utilité, le suivi de ses filles, les résultats atteints, etc. et comment faire pour améliorer ce volet?

14. Quel était le plus grand défi que vous avez dans le programme "Filles Éveillées "?

\section{Future}

15. Quel était la relation avec les autorités locales, les leaders communautaires ou la communauté ? Quelle pourrait être leur contribution pour le maintien des espaces sûrs? D'autres contributions?

16. L'Association Tié a exprimé son intérêt de répondre aux questions des filles qui sont victimes de violence, de grossesse non désirée, d'insécurité, ou qui ont d'autres problèmes chez leurs employeurs. Quelles sont 2 ou 3 idées pour répondre à ces différentes situations pour un plus grand effet ? Comment comptez-vous de façon pratique y procéder lorsque vous avez affaire à des cas concrets?

17. Quel rôle voyez-vous pour les filles qui ont déjà achevé le programme et qui vont revenir à Bobo après la saison des pluies? Par exemple, comme assistant au mentor ? Recruteuse ? Intermédiaire avec la communauté ?

18. Quel rôle voyez-vous pour les filles qui ont déjà achevé le programme et qui vont rester dans leur village d'origine définitivement?

19. Selon vous, comment le programme pourrait engager davantage les employeurs et les communautés? 


\subsection{Guide d'Entretien pour Membres de la Communauté}

Bonjour, et merci pour avoir accepté de participer à la discussion de groupe avec les membres de la communauté. Je suis et je suis ici pour apprendre un peu plus sur ce que vous pensez sur le programme "Filles Éveillées" et comment on pourrait l'améliorer.

En rappel, "Filles Éveillées" est un programme pour les jeunes filles migrées qui travaillent comme employées de maison. Durant huit (8) mois, les filles participent à une session chaque dimanche avec d'autres filles de leur âge et un mentor. Le programme cherche à développer des compétences chez les filles dans quatre domaines: les compétences de vie courante, la santé et l'hygiène, la santé de la reproduction, et les capacités financières.

On voudrait avoir toutes vos idées et aussi vos critiques positives ou négatives. N'hésitez pas à me dire aussi les choses négatives parce qu'on veut savoir aussi ce qui n'a pas marché pour améliorer lors de la deuxième phase du programme.

1. Est-ce que chacun de vous peut se présenter?

\section{Mise en œuvre/contenu}

2. Comment est-ce que vous avez connu ce programme pour la première fois? Comment est-ce que vous avez été informé de "Filles Éveillées" tout au long du programme?

3. Pouvez-vous nous dire brièvement ce que le programme fait? Comment le programme "Filles Éveillées" se distingue des autres programmes qui ciblent les filles employées de maison?

4. Selon vous, comment est-ce que ce programme pourrait enrichir davantage les filles/être profitable aux filles? Et la communauté?

5. Pour gagner le maximum de soutien de la communauté, comment est-ce qu'on peut ajuster nos principaux messages à la communauté?

6. Quelle pourrait être la contribution de la communauté pour le programme "Filles Éveillées "? (Par exemple, un espace sûr, d'alimentation pour les sessions, bancs pour chaque espace, contribution en espèces, etc.)

7. En plus des sessions communautaires, qu'est-ce qu'on peut faire pour renforcer l'engagement de la communauté dans le programme?

\section{Future}

8. Quel rôle voyez-vous pour les filles qui ont déjà achevé le programme? Par exemple, comme assistant au mentor? Recruteuse ? Intermédiaire avec la communauté ? Comment est-ce que les filles peuvent partager ses compétences et ses connaissances avec d'autres filles dans la communauté ?

9. Avez-vous quelques autres commentaires ou suggestions ? 


\subsection{Guide de Discussion de Groupe pour Filles qui ont Terminé le Programme}

Bonjour, et merci pour avoir accepté de participer à la discussion de groupe avec les autres filles qui ont complétées le programme "Filles Éveillées ". Je suis et je suis ici pour apprendre un peu plus sur ce que vous pensez sur le programme et comment on pourrait l'améliorer. On voudrait avoir toutes vos idées et aussi vos critiques positives ou négatives. N'hésitez pas à me dire aussi les choses négatives parce qu'on veut savoir aussi ce qui n'a pas marché pour améliorer lors de la deuxième phase du programme.

1. Est-ce que chacun de vous peut se présenter, et dire une chose que vous avez aimé dans le programme " Filles Éveillées "?

\section{Contenu}

2. Est-ce que les thèmes abordés par le programme étaient pertinents pour vous et utiles dans votre vie ? Quels sont 2 ou 3 choses que vous savez faire maintenant et que vous ne saviez pas faire avant de participer au programme?

3. Quelles sont les deux sessions ou sujets qui étaient les plus utiles pour vous ? Quelles sont les deux sessions ou thèmes qui étaient les moins utiles pour vous? Pourquoi?

4. Quel sont les thèmes qui n'ont pas été couverts par le programme et qu'on pourrait abordés s'il y avait une suite? Et pourquoi?

\section{Mise en œuvre du programme}

5. Est-ce que le programme "Filles Éveillées " contribue à répondre à vos besoins? Qu'est-ce que l'on pourrait faire pour mieux répondre à vos besoins?

6. Qu'est-ce que vous pensez sur les visites à domiciles ? Est-ce qu'elles étaient utiles pour vous et pour vos employeurs? Pourquoi?

7. Qu'est-ce que vos employeurs pensent du programme ? Est-ce qu'ils soutiennent votre participation? Pourquoi ? Est-ce que vos relations avec vos employeurs ont changé de quelque manière à cause du programme?

8. Est-ce que vous pouvez me décrire votre relation avec votre mentor? Est-ce que vous lui demandiez des conseils ou bien avez vous confiance que vous pouvez lui demander des conseils en cas de besoins ou vous confier à elle? Vous vous sentiez à l'aise avec elle? Selon vous, quelles qualités sont les plus importantes chez un mentor?

9. Vous vous sentiez à l'aise avec les autres filles de votre groupe ? Pourquoi ? Est-ce que l'âge des autres filles est un facteur important pour vous pour se sentir à l'aise?

\section{Structure}

10. Qu'est-ce que vous pensez de la durée du programme ? (Pour celles qui ont fait 4 mois, demandez-leur si elles sont prêtes à participer à 8 mois de programme.) Que pensez-vous de la durée et la fréquence des sessions? (une fois par semaine et si c'est deux fois dans la semaine ?) Le temps était-il suffisant pour comprendre le contenu de la session?

11. Selon vous, comment est-ce que vous pouvez contribuer à appuyer les filles de la $2^{\text {ème }}$ cohorte du programme ? Expliquer quel pourrait être votre rôle (à Bobo ou au retour au village). Est-ce que vous pensez que vous allez partager les informations 
que vous avez apprises aux filles lorsque vous retournerez dans votre village? Comment allez-vous procéder?

12. Quel était le plus grande défi pour vous dans le programme "Filles Éveillées "?

13. Est-ce que vous recommanderiez ce programme aux autres filles comme vous? Pourquoi?

Fin

14. Avez-vous d'autres commentaires ou observations? 


\subsection{Guide d'Entretien pour les Employeurs}

Bonjour, et merci pour avoir accepté de participer à un entretien avec moi. Je suis et je suis ici pour apprendre un peu plus sur ce que vous pensez sur le programme "Filles Éveillées " et comment on pourrait l'améliorer.

En rappel, "Filles Éveillées" est un programme pour les jeunes filles migrées qui travaillent comme employées de maison. Durant huit (8) mois, les filles participent à une session chaque dimanche avec d'autres filles de leur âge et un mentor. Le programme cherche à développer des compétences chez les filles dans quatre domaines: les compétences de vie courante, la santé et l'hygiène, la santé de la reproduction, et les capacités financières.

On voudrait avoir toutes vos idées et aussi vos critiques positives ou négatives. N'hésitez pas à me dire aussi les choses négatives parce qu'on veut savoir aussi ce qui n'a pas marché pour améliorer lors de la deuxième phase du programme.

\section{Contenu}

1. Pouvez-vous nous dire brièvement ce que le programme "Filles Éveillées " fait? Qu'est-ce qui vous a le plus plu dans le programme "Filles Éveillées " ?

2. Comment le programme "Filles Éveillées " se distingue des autres programmes qui ciblent les filles employées de maison?

3. Est-ce que vous pensez que votre employée a profité de ce programme ? De quelle manière ? Comment le savez-vous?

4. En tant qu'employeur, avez-vous profité de ce programme? Pouvez-vous nous donner quelques exemples concrets ? Est-ce que votre employée a souvent raconté à la famille ce qu'elle a appris aux sessions?

5. Qu'est-ce qui ne vous a pas plu dans le programme "Filles Éveillées " et mérite d'être amélioré? Quelles propositions faites-vous pour l'améliorer?

\section{Mise en œuvre du programme}

6. Est-ce que vous pensez que le programme "Filles Éveillées" est une approche appropriée/un programme pertinent pour aborder les défis que les filles migrantes rencontrent ? Qu'est-ce que l'on pourrait faire pour l'améliorer?

7. Qu'est-ce que vous pensez des visites à domicile et qu'est-ce que vous avez discuté avec le mentor lors de ces visites? Est-ce que les visites à domicile étaient utiles ?

8. Est-ce que vous avez participé à quelques sessions communautaires du programme? Qu'est-ce que vous en pensez? Que peut-on améliorer dans ces sessions communautaires?

\section{Structure}

9. II y a 8 mois de cela (ou 4 mois pour les nouveaux groupes), lorsque les mentors sont venues vous expliquer le programme, vous avez donné votre accord à ce que votre employée participe au programme. Quelles sont les difficultés que vous avez rencontrées par la suite qui ont empêché votre employée de venir régulièrement aux sessions les dimanches? 


\section{Pour terminer}

10. Est-ce que vous recommanderiez ce programme aux autres employeurs et aux autres employées? Pourquoi/pourquoi pas? Est-ce que vous laisseriez ou encourageriez votre future employée à y participer?

11. Avez-vous d'autres commentaires ou suggestions ? 


\section{ANNEX 2: MONITORING AND EVALUATION TOOLS³}

\subsection{Canevas d'Appréciation des Sessions}

Ce canevas doit être rempli par le mentor à chaque session

Date :

Ville/Site/espace sûr :

Nom de l'association :

Nom du mentor :

Nom du groupe :

Session abordée (numéro et titre) :

Utilité de la session pour les filles :

Utile

Moyennement utile I__ I

Pas utile I_I

Appréciation de la durée de la session :

Longue I

Acceptable I__

Trop courte I_LI

Pertinence des exercices de la session :

Pertinent I

Assez pertinent

Pas pertinent

Compréhension des exercices de la session par les filles :

Bonne compréhension

Compréhension moyenne I_L

Pas compréhensible

Compréhension/clarté de la session :

Bonne compréhension par les filles I

Compréhension moyenne I

Compréhension difficile I

Difficultés rencontrées par le mentor dans l'animation de la session :

Suggestions de solutions:

Aspects/points de la session à améliorer :

\footnotetext{
3 The monitoring and evaluation tools in this Annex are the versions used from 2011 to 2012. Updated versions have been created and are being circulated among implementing organizations. Final versions will be provided to the donor as soon as they are complete.
} 
Suggestions globales sur la session:

Signature du mentor : 


\subsection{Tableau de Présence des Filles aux Sessions}

Date : - Ville/Site/Espace sûr :

Secteur/quartier :

Nom de l'association :

Nom du mentor :

Nom du groupe :

NB : Cette fiche est conçue pour chaque groupe et les noms des filles peuvent être préalablement notés. A chaque session, il vous suffit de cocher la case correspondante lorsque la fille est présente. Cette fiche doit être remplie par le mentor.

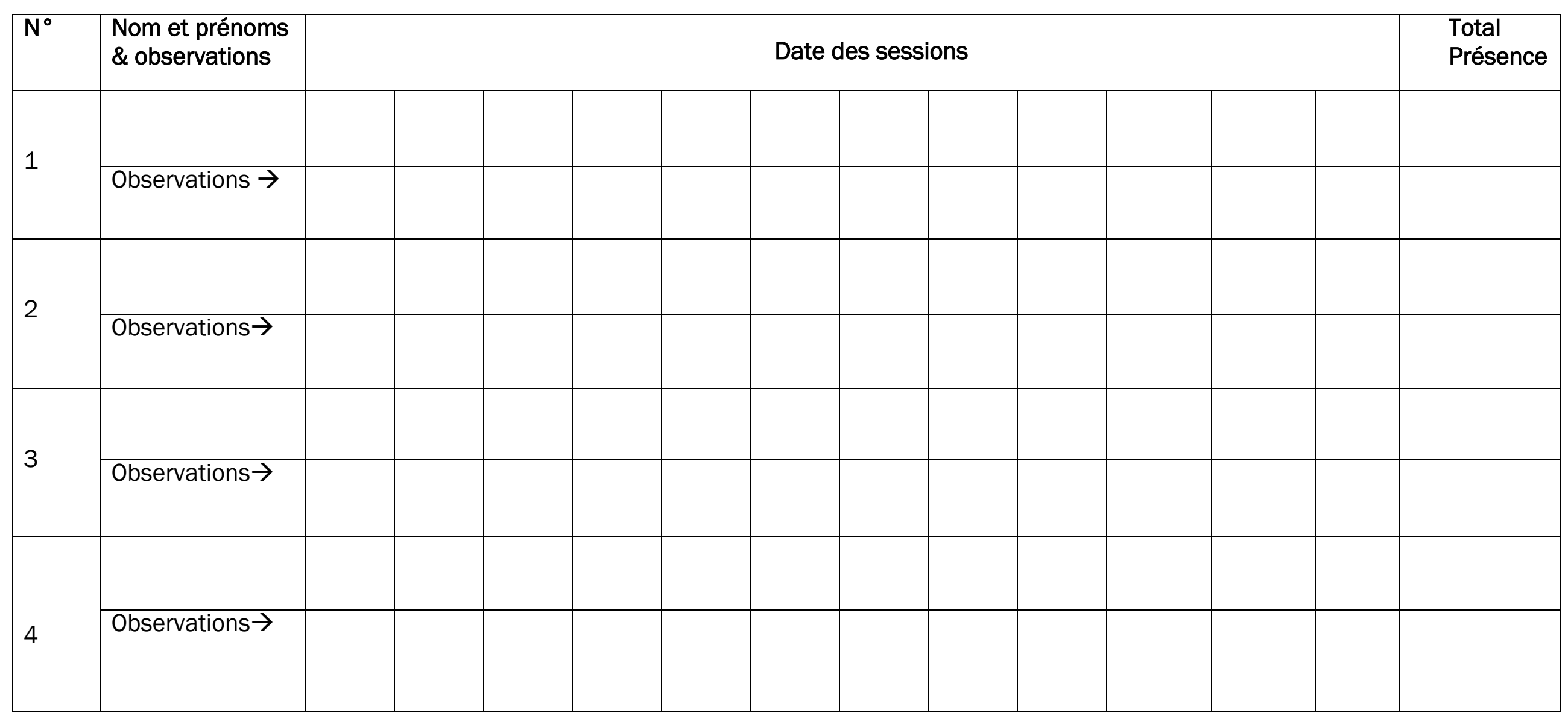




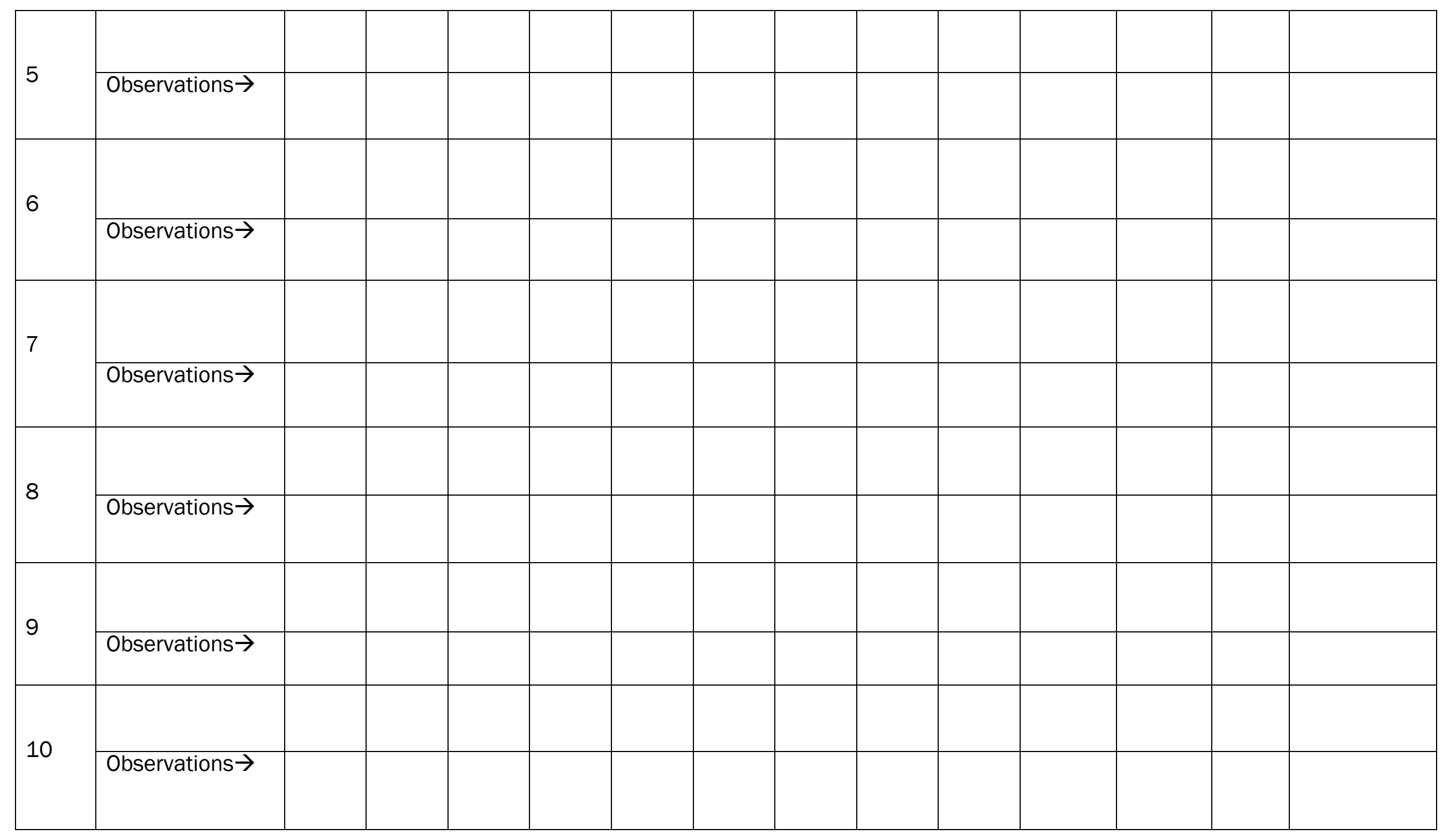




\subsection{Fiche Individuelle des Visites à Domicile}

Cette fiche doit être remplie à chaque fois que le mentor effectue une visite d'une fille à domicile.

Date :

Ville/Site/Espace sûr :

Secteur/quartier :

Adresses du domicile de la fille:

Nom de l'association :

Nom du mentor:

Nom du groupe :

Nom et prénom de la fille :

Âge de la fille :

Qui était présent(e) (fille seule, avec employeur, ...) :

Objet de la visite :

Contenu de la visite :

Compte rendu narratif (expliquer comment s'est passée la visite, les résultats constatés, etc.).

Date probable de la prochaine visite:

Motif de la prochaine visite:

Signature : 


\subsection{Fiche de Supervision des Activités des Mentors}

Cette fiche doit être remplie par le chargé de programme ou toute autre personne de l'association qui effectue une supervision du travail du mentor.

Date :

Ville/Site :

Secteur/quartier:

Nom de l'association:

Nom du mentor :

Nom du groupe :

Nom du superviseur :

Objectifs de la supervision:

Thème de la session:

Constats:

\section{Appréciation du déroulement de la session}

Par rapport au mentor:

Par rapport à la participation du groupe:

Par rapport aux approches utilisées:

Points forts:

Points à améliorer:

Signature du superviseur : 


\subsection{Canevas de Rapport Narratif des Associations}

Ce canevas est proposé pour le rapport trimestriel des associations

\section{Page de garde}

Date :

Ville/Site :

Secteur/quartier:

Nom de l'association:

Période du rapport :

\section{Partie narrative}

Contexte/Intro

Objectifs

Résultats Attendus

Description et analyse des activités réalisées (mettre l'accent sur l'intérêt des participantes par rapport au programme, les faits marquants, le degré de participation des filles au programme, qu'est ce qui a marché, qu'est-ce qui mérite d'être améliorer, ..)

Difficultés rencontrées

Leçons apprises

Suggestions et Recommendations

\section{Leçons apprises (Fiche d'orientation)}

\begin{tabular}{|c|l|l|}
\hline Domaines et sujets & Constats & Leçons apprises \\
\hline $\begin{array}{l}\text { Qu'avez-vous appris dans le travail avec } \\
\text { les filles employées de maison? }\end{array}$ & & \\
\hline Avec les employeurs & & \\
\hline Avec les mentors & & \\
\hline $\begin{array}{l}\text { Dans l'approche de passer par des } \\
\text { mentors pour mettre en œuvre le } \\
\text { programme }\end{array}$ & & \\
\hline Dans la Mobilisation des communautés & & \\
\hline $\begin{array}{l}\text { Dans la Mobilisation des filles du } \\
\text { programme }\end{array}$ & & \\
\hline Par rapport au contenu du programme & & \\
\hline $\begin{array}{l}\text { Par rapport aux approches utilisées pour les } \\
\text { sessions }\end{array}$ & & \\
\hline $\begin{array}{l}\text { Par rapport à l'approche de travailler } \\
\text { avec des partenaires }\end{array}$ & & \\
\hline Etc. & & \\
\hline
\end{tabular}




\subsection{Canevas du Rapport des Enseignants sur l'Encadrement des Filles du Programme}

Ce canevas doit être renseigné par l'enseignant tous les 2 mois.

Période du rapport :

Secteur:

Nom de l'enseignant:

Etablissement :

Nombre de filles inscrites:

Nombre de filles qui viennent régulièrement ( $90 \%$ ou plus) :-

Classes couvertes : CP1 ( ) CP2 ( ) CE1 ( ) CE2 ( ) CM1 ( ) CM2 ( ) 6ème ( )

Appréciation de la participation des filles (l'assiduité et participation aux cours, la motivation...)

Progrès fait durant la période :

Difficultés rencontrées :

Suggestions et recommendations :

Signature de l'enseignant

Visa Association Tié 